\title{
CONTRACTS IN THE AGRI-FOOD SUPPLY CHAIN WITHIN THE FRAMEWORK OF THE NEW COMMON AGRICULTURAL POLICY
}

\author{
Luigi RUSSO \\ PROFESSORE ASSOCIATO DI DIRITTO AGRARIO \\ UNIVERSITÀ DEGLI STUdi DI FERRARA
}

SUMARIO: I. Identification of the scope of the present paper: contracts within the framework of the CAP. II. POs and IOs in the new regulation on the CMO of agricultural products. III. (continued): possible formalisation through written contracts for the delivery of products falling within the scope of the CMO. IV. (continued): power to engage in contractual negotiations attributed to some POs under regulation (EU) No. I308/2013. V. Antitrust rules in Regulation (EU) No. 1308/2013 and their inadequacy for the purposes of protecting agricultural producers vis-à-vis the market.

RESUMEN: Se pretende examinar las medidas previstas en el Derecho de la UE verificando cómo y en qué modo se afronta la problemática que la reforma de la PAC del 2003 primero, y del 2013 después, han comportado para los productos agrícolas. Las reformas han modificado radicalmente el cuadro de acciones de PAC, sustancialmente eliminando la forma de gestión del Mercado realizando ulteriores reducciones en el importe de las ayudas acopladas en favor de un improvisado paso a un sistema fundado en pagos directos, en gran parte desacoplados de la producción. Como resultado, los productos agrícolas se han encontrado expuestos a una competencia a escala mundial sin una protección real.

Palabras ClaVE: Política Agrícola Común. Organizaciones de Productores. Organizaciones Interprofesionales. Asimetría del poder negociador.

ABSTRACT: The paper is focused on the measures provided for under new EU regulations in an attempt to address the problems arising for the agricultural producers by the CAP reforms of 2003 and 20I3; with these reforms the Community radically modified the framework of its agricultural policy, substantially eliminating the (already reduced) forms of market management and making further substantial cuts in the amount of coupled support in favour of an almost sudden (and improvised) switch to a system of direct payments to farmers, largely decoupled from production, as a means of supporting the income of agricultural producers. As a result, the latter suddenly found themselves exposed and forced to operate not on a European scale but rather in a global market, and what is more without any forms of protection.

KeYwORDS: Common Agricultural Policy, Producer Organisations, Interbranch Organisations, Asymmetry Of Bargaining Power. 


\section{Identification of the scope of the present paper: contracts within the framework of the CAP.}

In 2013, European legislators once again focused their attention on the Common Agricultural Policy and approved a series of new regulations intended, in principle, to remain in force until 2020 , though many provisions will most likely have a shorter life, as a midterm «fine-tuning» may be expected soon.

Notwithstanding the new regulations, the reform does not contain any elements representing a break with the previous rules, but may rather be seen as a refinement and evolution of pre-existing legislation.

Accordingly, the policy of intervention continues to be divided into two pillars. The first pillar still uses up the majority of the allocated resources. However, these have seen a reduction compared to the budget previously assigned to the CAP, obliging European institutions to redistribute the fewer available resources with greater caution, and the farmers concerned to get by with less financial support.

With regard to the first pillar, the policy pursued is still based, in principle, on decoupled subsidies, though with a segmentation of direct payments, formerly unitary, into a multiplicity of subsidies, some of which compulsory and others left to the initiative of the Member States. Worthy of note among the compulsory payments, from a political standpoint even more so than a legal and agronomic one, are the ones conditional upon the recipient's observance of practices that are beneficial for the climate and the environment.

The rules on cross-compliance have remained, but they are now better coordinated, also with respect to their application to some rural development schemes, and have been encapsulated within a specific regulation of a horizontal character which includes provisions for the control and operation of agricultural funds ${ }^{2}$.

With regard to the CMO, Regulation No. I234/O7 was replaced by Regulation (EU) No. 1308/2013, which maintains the same scheme as its predecessor, regulating the operation of the markets in agricultural products with a legislation that is based on a generally unitary approach but includes numerous provisions dedicated to individual products ${ }^{3}$.

Cf. Regulation (EU) No. 1307/2013 of the European Parliament and of the Council of I7 December 2013 establishing rules for direct payments to farmers under support schemes within the framework of the common agricultural policy and repealing Council Regulation (EC) No. 637/2008 and Council Regulation (EC) No. $73 / 2009$.

${ }^{2}$ See Regulation (EU) No. I306/20I3 of the European Parliament and of the Council of I7 December 2013 on the financing, management and monitoring of the common agricultural policy and repealing Council Regulations (EEC) No. 352/78, (EC) No. I65/94, (EC) No. 2799/98, (EC) No. 8I4/2000, (EC) No. I290/2005 and (EC) No. $485 / 2008$.

${ }^{3}$ Cf. Regulation (EU) No. 1308/2013 of the European Parliament and of the Council of I7 December 2013 establishing a common organisation of the markets in agricultural products and repealing Council Regulations (EEC) No. 922/72, (EEC) No. 234/79, (EC) No. I037/200I and (EC) No. I234/2007. 
As for the second pillar, the new regulation ${ }^{4}$ continues to provide a sort of menu of measures adoptable by Member States, which are called upon to co-finance expenditure through specific rural development plans to be adopted on a regional or national level.

In general terms, the legislation confirms a policy already enshrined in EU law since 2003 , aimed at regulating an agriculture that enjoyed very little protection and was largely left at the mercy of market dynamics. However, farmers benefiting from the various support measures are now asked not only to increase their competitiveness and efficiency, but also to engage in a series of practices deemed virtuous from an environmental perspective, aimed at minimizing the impact of production activities on the environment. This has inevitably meant higher costs and greater burdens (in addition to a more extensive activity of verification and control) and reduced farm productivity.

As mentioned, the recent Regulation (EU) No. 1308/2013 contains the current rules governing the common organisation of the market in agricultural products, which replaces those laid down in Regulation (EC) No. I234/2007. In light of the title given to this paper, it is not necessary - nor would it be possible - to cover the entirety of the body of the text, consisting in 232 articles and I4 annexes: what is of relevance here is to assess how the European legislator intended to address the substantial removal of the protection originally offered to producers by the CMO, given that the dismantling of the basic framework of the CMO (including price support and export refunds) has necessarily entailed introducing new instruments to protect agricultural producers: in the absence of any protection measure, they would be unable to survive in a particularly competitive world context in which European agriculture is at a disadvantage.

In fact, due to the peculiarities of the agricultural market and of the producers involved, there is a marked - and structural - assymetry of bargaining power between those who place agricultural products on the market and those who intend later to sell or process them ${ }^{5}$. Precisely for this reason, the particular characteristics of the agricultural sector imply (or rather, impose, if the aim is to maintain an active primary sector spread across the territory) a need for a differentiated treatment in law - based on a series of protective measures - for farmers as compared to other business categories.

The action of the European Community in the agricultural sector, since the original outlining of principles and objectives in the Treaty of Rome, has been characterised by elements of a special, if not exceptional, nature. These are still present in the current TFEU, as demonstrated by the provision for a veritable sector «policy» to be implemented on a Community level (CAP), as well as the presence of an agricultural market that is still today (albeit to a lesser extent than in the past) managed and supervised at a central level, rather than being left to its own devices (see Article $40 \mathrm{TFEU}$ ) and a potential exemption of the

\footnotetext{
${ }^{4}$ Regulation (EU) No. 1305/20I3 of the European Parliament and of the Council of I7 December 2013 on support for rural development by the European Agricultural Fund for Rural Development (EAFRD) and repealing Council Regulation (EC) No. I698/2005.

${ }^{5}$ For an analysis of the market in non-processed agricultural products and processed food products, see the Commission Staff Working Document Competition in the food supply chain, Accompanying document to the Communication from the Commission to the European Parliament, the Council, the European Economic and Social Committee and the Committee of the Regions, A better functioning food supply chain in Europe, dated 28.10.2009, COM (2009) 591.
} 
agricultural sector from competition rules (cfr. Article 42 TFEU), whose scope is left up to the discretion of the European legislator ${ }^{6}$.

Community agricultural policy - founded $a b$ origine on the articles of the EEC treaty dedicated to agriculture and left almost unchanged despite the amendments since introduced - has proven to be particularly incisive. It has come to commit over half of total Community expenditure in order to provide support, in a whole variety of forms, to the European agricultural production sector and enable the latter not only to consolidate its position and increase production and productivity, but also to compete on international markets. For this purpose it has used particularly effective tools such as price policy, levies on imports and export refunds.

However, starting from the early I990s, the CAP began to undergo a crisis for a variety of reasons, major ones being - on the Community level - the financial unsustainability of such pervasive intervention and the concerns caused by the massive exploitation of land and, more generally speaking, environmental resources, as a consequence of incentives directly tied to the quantities produced, which drove producers to increase the productivity of their farms with the aim of obtaining larger and larger amounts of products. On an international level, it is important to consider the new constraints imposed on the European Community by the then newborn World Trade Organisation (W.T.O.) and the treaties accompanying its creation, designed to favour the opening of the EC market to the dynamics of a world market in agricultural products that would be contaminated as little as possible by distortionary interventions tied to the aid provided by states: these restrictions imposed a generalised reduction on support measures and at the same time a partial transition from measures coupled to production, deemed incompatible with the principles of a globalized market, to decoupled payments, as well as the removal of such highly effective import barriers as levies, to be replaced with fixed duties, and a reduction support for exports.

Also (but not only) with an eye to implementing in advance the anticipated further developments of the agreement on agriculture reached within the W.T.O., the Community thus radically modified the framework of its agricultural policy. It reformed the guidelines of the CAP in 2003 (mainly with Regulation No. I782/O3), substantially eliminating the (already reduced) forms of market management and making further substantial cuts in the amount of coupled support in favour of an almost sudden (and improvised) switch to a system of direct payments to farmers, largely decoupled from production, as a means of supporting the income of agricultural producers?.

As a result, the latter suddenly found themselves exposed and forced to operate not on a European scale but rather in a global market, and what is more without any forms of protection. Producers could no longer count on the artificial isolation - ensured by a CAP

\footnotetext{
${ }^{6}$ For a basic outline, see SGARBANTI, Le fonti del diritto agrario, I, Le fonti costituzionali e comunitarie, Padova, I988; see also the comments sub Arts. 38 to 44 TFEU, in Commentario breve ai Trattati dell'Unione europea, II ed., a cura di POCAR e BARUfFi, Padova, 20I4.

7 On this subject see Costato, Regime disaccoppiato, Trattato di Lisbona e obiettivi della PAC verso il 2020, in Agricoltura Istituzioni, Mercati, 20II, I3 ff.; AlbisinNi, Profili di diritto europeo per l'impresa agricola. Il regime di aiuto unico e le attività dei privati, Viterbo, 2005; ID., Il regime di aiuto unico, in Il contenzioso sui regimi di pagamento in agricoltura, a cura di AlBisinni e SCIAUdone, Naples, 2008, $69 \mathrm{ff}$.
} 
that been left unchanged since its inception in the early I960s - of the European market from the world market ${ }^{8}$.

The economic and cultural leap that the newly defined CAP implied for farmers was enormous and above all took place with a minimal transition period, as well as in the absence, for the most part, of adequate education and information about the new rules?

It is thus not surprising that just a few years after the reformed CAP entered into force, the supply-side weaknesses that had always been inherent to agricultural markets were exacerbated. Given the lack of any price stabilisation mechanism (though such mechanisms are envisaged by Article 39 TFEU, whose contents have never been amended since the original EEC treaty ${ }^{\mathrm{IO}}$ ), over this brief period European producers had to cope for the first time with the high volatility of the prices of many agricultural commodities. The European market had been subject to price volatility in the past, but thanks to the protection provided by the CAP, it had had no real impact for European producers, who could count on the protection provided by levies on imports and the generous price policy managed by the Community. Therefore, as early as 2007 , the European agricultural market felt the repercussions of a series of strong fluctuations in global prices of many agricultural commodities, ascribable to several factors: the increase in the world demand for food, the use of some crops for non-food purposes, trade restrictions and adverse climatic events that on various occasions affected states that were major producers of certain products, causing drastic declines in harvests which in turn led almost immediately to price surges in the European market .

At the same time, the removal of import barriers - transformed from variable levies into fixed duties, with a parallel reduction in the respective amounts - implied exposing farmers to a competition from non-European producers that had been practically unknown in the past ${ }^{2}$.

These «new» factors have therefore aggravated the fragility of the agricultural sector, especially in the trade relations with counterparty buyers, which represent the necessary outlet for farm products and do not suffer from the effects of small size, unlike a large part

\footnotetext{
${ }^{8}$ Cf. DE FILIPPIS, La volatilità dei mercati agricoli mondiali: le cause, gli effetti, le politiche possibili, in Riv. dir. alim., 2012, n. 4, I9 ff.

${ }^{9}$ One author particularly critical of a CAP having little regard for the objectives of Art. 39 TFEU is CoSTATO, La riforma della PAC del 2003 e le norme agrarie del trattato, in Riv. dir. agr., 2005, I, 478 ff.; ID., Attività agricole, sicurezza alimentare e tutela del territorio, ivi, 2008, I, 453; ID., Il nuovo diritto agrario comunitario: diritto agrario $o$ diritto ambientale?, in Dir. giur. agr. alim. amb., 2007, 577 ff.; ID., Riforma della PAC e rifornimento dei mercati mondiali di prodotti agricoli alimentari, ivi, 20II, 87 ff.; ID., La PAC riformata, ovvero la rinuncia a una politica attiva, in Rivista di diritto agrario, 2012, I, $393 \mathrm{ff}$.

${ }^{10}$ Cf. Adornato, Agricoltura, politiche agricole e istituzioni comunitarie nel trattato di Lisbona: un equilibrio mobile, in Riv. dir. agr., 20Iо, I, 266; AlBisinNi, Istituzioni e regole dell'agricoltura dopo Lisbona, ivi, 20Iо, I, 2IO ff.; BIANCHI, La Pac «camaleontica» alla luce del Trattato di Lisbona, ivi, 2009, I, 592 ff.

${ }^{\text {II }}$ Cf. Costato, Dalla Food security alla Food insecurity, in Riv. dir.agr., I, 2OII, 3 ff.; JANNARELl, La nuova food insecurity: una prima lettura sistemica, in ID., Profili giuridici del sistema agro-alimentare tra ascesa e crisi della globalizzazione, Bari, 20II, 273 ff.; GERMANÒ-ROOK BASILE, Il diritto dei mercati dei prodotti agricoli nell'ordinamento internazionale. Corso di lezioni, Turin, 20Io. For an analysis on this topic, see the Communication from the Commission to the European Parliament, the Council, the European Economic and Social Committee and the Committee of the Regions of 9.I2.2008 COM (2008) 82I, Food Prices in Europe.

${ }^{12}$ On the effects of the accession of the EU and its individual Member States to the agreements reached within the framework of the WTO, see BoRGHI, L'agricoltura e il Trattato di Marrakech. Prodotti agricoli e alimentari nel commercio internazionale, Milan, 2004.
} 
of agricultural enterprises; purchasing companies, in fact, are generally significantly larger than farms. In addition, they were already accustomed to having to confront competitors on the European market, not being able to rely on a set of special protective regulations such as those applied for farmers.

It is thus by now clear that at present - taking account of the choices made within the framework of EU law, which seem no longer reversible, at least in the short term - we are witnessing a situation that can be defined as a veritable emergency, given that under EU policies farmers are supposed to compete on the market like any other economic operator. However, an attempt (at least) should be made to attenuate the excessive inequality of bargaining power presently existing between the supply and demand sides in respect of agricultural products ${ }^{\mathrm{I3}}$.

In other words, whereas in the past, by virtue of the strong protection guaranteed to farmers by the price policy and market control mechanisms, means of protection operating on a contractual level could be considered of secondary importance, the disappearance of the former has inevitably resulted in the need (assuming, of course, that maintaining a significant European agricultural production is deemed a strategic objective) to reinforce the latter, so as to preserve an essential balance between the two players in the agricultural market.

In this paper, therefore, attention will be focused on the measures provided for under new EU regulations in an attempt to address the problems just highlighted.

In this regard, two main lines of action can be seen in the EU's intervention in the agricultural products market: i) the first is founded on the formation of agricultural and interbranch associations (POs and IOs), and on the possible compulsory extension of their decisions to non-members as well; accordingly, the new legislative text includes some nonminor innovations that are substantially designed to increase the tasks of private associations with the aim of strengthening the supply side of the food and agricultural products sector; ii) the second is centred upon the possible introduction - at the initiative of Member States, within the framework of legislation conceived at the Union level - of written contracts between farmers and first purchasers of agricultural products.

If we take a closer look, we will see that the European legislator has also devised a third form of intervention, albeit only for certain production sectors. The aim is to reinforce the contractual position of farmers by empowering POs to engage in contractual negotiations with counterparties so as to conclude framework agreements that each member can later make reference to when negotiating contracts individually, so as to try to overcome the weaknesses of the sectors concerned.

This marked attention to the role of private associations and the contractual relations between the players in the market for agricultural products appears, moreover, to be an almost necessary outcome of the events that have affected the agricultural sector at the level of law following the latest reforms.

${ }^{13}$ Cf. Resolution of the European Parliament of 7 September 2010 on fair revenues for farmers: A better functioning food supply chain in Europe, (2009/2237 (INI)), in which an account is given of the major imbalances characterising the agricultural market. 
The protection of agricultural producers is thus no longer - or not only - provided by instruments of public law, though these are present and take on a central role in the system. It progressively also involves reliance on contractual arrangements of a different nature and raison d'être, but which in any case are designed to furnish support to farmers, objectively the weakest party within the agricultural market.

Whether we are talking about horizontal or interbranch associations or the rules largely inadequate, as we shall see better - governing contracts for the first purchase of agricultural products, or contractual negotiations conducted by such organisations, it is always a question of contractual models: for the formation of associations, in the case of POs or IOs, and for trade purposes in the case of contracts with first purchasers of products or negotiations conducted by POs.

These are thus the types of contracts involving agricultural producers and which at present are of most interest to legal scholars: in other words, the new delivery contracts of the agricultural and food products market, which have taken the place, in terms both of importance and problems, of the «old» agricultural leases, i.e. those whereby agricultural producers procured their main means of production, such as land or animals ${ }^{\mathrm{T} 4}$.

Given the availability of farmland and the modest percentage of the population employed in agriculture, at least in the old EU Member States, the tensions between owners leasing out property and the tenants have substantially disappeared, as there no longer exists a demand for land such as to induce landlords to engage in abusive behaviour vis-àvis those who used to be the weaker parties in the relationship since they needed a piece of land to farm ${ }^{\mathrm{r}}$.

The scope of inquiry having thus been defined, we shall now consider, in order, the provisions of EU Regulation No. 1308/2013 concerning agricultural and interbranch associations; the rules concerning the possible formalisation of contracts concluded with first purchasers of agricultural products; and the legislation concerning the power of POs to engage in contractual negotiations.

\section{POs and IOs in the new regulation on the common organisation of markets in agricultural products (CMO).}

The new EU single CMO regulation No. 1308/2013 reaffirms the prominent role that European law attributes to producer organisations $\left(\mathrm{POs}^{16}\right)$ and interbranch organisations $\left(\operatorname{IOs}^{17}\right)$ for the purposes of improving the market competitiveness of farmers

\footnotetext{
${ }^{14}$ On this subject, reference may be made to RUSSo, «I nuovi contratti agrari», in Riv. dir. agr., 20I3, I, $36 \mathrm{ff}$.

${ }^{15}$ Indeed, at present it is not uncommon to see a complete turning of tables in the balance of power, so that the landlord has become the weaker party in the relationship.

${ }^{16}$ Pursuant to Art. I52 of the regulation, POs are constituted and controlled by producers in a specific sector among those falling within the single CMO.

${ }^{17}$ Pursuant to Art. I57(I) a) of the regulation, IOs «are constituted of representatives of economic activities linked to the production and to at least one of the following stages of the supply chain: the processing of or trade in, including distribution of, products in one or more sectors».
} 
and extends the solutions previously envisaged for the milk and milk products sector alone to all sectors of the $\mathrm{CMO}^{\mathrm{r}}$.

Further strengthening the role of POs and IOs thus appears to be a sort of necessary choice for the EU legislator, given the hope that the aggregation achieved through such organisations will serve to reduce the existing gap in economic power between the parties in the market for agricultural products.

Concerning this point it should be noted first of all that the new legislative text reiterates the power of Member States to recognise, in all sectors of the CMO, both POs (Article I52) and IOs (Article I57 et seq.) ${ }^{\text {I9 }}$, though with greater clarity and emphasis ${ }^{20}$ than in the legislation previously in force.

Moreover, the regulatory framework is defined in a manner that is undoubtedly simpler and more orderly than before; on this point Regulation No. 1234/2007 suffered from the effects of a multitude of subsequent legislative acts that expanded the provisions dealing with POs and IOs. Suffice it to say that Chapter II - dedicated precisely to such organisations - of Title II (rules applicable to marketing and production) of Regulation I234/2007 was originally composed of only six articles (I22 to I27), whereas at the time of its repeal it consisted of no fewer than 25 articles. The result was a patchwork of provisions that in a large part of cases were sector-specific, in contradiction with the concept of a single CMO: one need only consider that Chapter II, dedicated to POs and IOs, as well as Section I, containing the general principles, and Section II on IOs in the tobacco sector were progressively supplemented with Section Ib, related to said organisations in the fruit and vegetables sector (Articles I25 b to I25n) ${ }^{2 \mathrm{I}}$, Section Ic, dedicated to POs and IOs in the wine sector (composed solely of article I250) ${ }^{22}$ and Section IIb, on POs and IOs in the milk and milk products sector (articles $126 \mathrm{~b}$ to $126 \mathrm{e})^{23}$.

The present regulation likewise differentiates among production sectors in some respects; however, the sector-specific provisions are clearly «confined» in a special Section ${ }^{24}$, simplifying their interpretation. The obligatory recognition of POs and IOs only for certain sectors has been maintained: as for POs, under Article I59 of Regulation No. 1308/2013,

\footnotetext{
${ }^{18}$ The CMO in the fishery and aquaculture products, governed by Regulation (EU) No. I379/2013 of the European Parliament and of the Council of II December 2013 on the common organisation of the markets in fishery and aquaculture products, amending Council Regulations (EC) No. II84/2006 and (EC) No. I224/2009 and repealing Council Regulation (EC) No. I04/2000, in OJEU L 354/13, lends importance to the role of the POs, so much so that Art. I(2) establishes that the CMO in question «shall be comprised of the following elements: a) professional organisations; b) marketing standards; c) consumer information; d) competition rules; e) market intelligence».

19 With regard to the former legislation, Art. I22 et seq, Regulation (EC) No. I234/2007, see FERRUCCISTRAMBI, «Commento agli artt. I22 - I27», in Il regolamento unico sull'organizzazione comune dei mercati agricoli, a cura di Costato, in Le nuove leggi civ. comm., 2009, I33 ff.

${ }^{20}$ The previous legislation provided, in Art. I22, for the possibility of compulsory recognition and, in Art. I24 of Reg. No. I234/2007, an option for Member States to recognise POs (or IOs) in any other sector governed by the regulation itself; with Regulation (EC) No. 72/2009, moreover, a paragraph was added to Art. I22 which stated expressly that Member States could recognise POs constituted by producers in any sector covered by the single CMO.

${ }^{21}$ Introduced by Regulation (EC) No.36r/2008.

${ }^{22}$ Introduced by Regulation (EC) No.49I/2009.

${ }^{23}$ Introduced by Regulation (EU) No.26I/20I2.

${ }^{24}$ Section 2 , headed «Additional rules for specific sectors», comprised of articles 159 to 163 .
} 
recognition is obligatory in the fruit and vegetables sector, olive oil and table olives sector, the silkworm sector and hops sector (to this list we must add the milk and milk products sector, for which recognition of POs is obligatory as per Article I6I); Article I59 b) similarly provides for IOs in the olive oil and table olives sector and tobacco sector ${ }^{25}$.

The tasks attributed to $\mathrm{POs}^{26}$ include concentration of supply through direct marketing of members' products; adjusting production to demand in terms of quantity and quality; drawing up standard contracts for the delivery of agricultural products; carrying out research activity geared toward innovation; improving the orientation of production; and restricting the use of animal health or plant protection products. A complete list of the objectives pursued by POs is given in Article I52 of the regulation, which specifies that they need not all be necessarily implemented, it being sufficient that at least one of them is included among their activities ${ }^{27}$.

In addition to the provisions of a general character, the regulation lays down specific rules for POs operating in certain sectors. Under Article I60, which concerns POs in the fruit and vegetables sector, the statutes of such organisations must require members to market the entirety of their production through the PO itself and the scope of the activities that the POs are call upon to carry out is narrowed.

Compared to the former Regulation I234/07, therefore, the new legislation considerably broadens the range of activities that POs may concretely engage in; however, the list of activities is not necessarily binding for every recognised PO, since the provision clearly states that a PO can be constituted and recognised even if it carries out only one of the activities specified. However, as a result the very notion of a PO loses much of its meaning, given that organisations conducting activities having a very different scope and impact - with the exception of POs in the fruit and vegetables sector, which have always played a role of particular importance in the target market concerned - are lumped together under the same designation: an organisation that directly markets the production of its members, acting as trading partners of purchasers, may be considered a PO, but so can one that limits itself to providing technical support in the implementation of environmentally friendly cultivation practices and production techniques, or overseeing the management of by-products and waste (as mentioned, for example, in Article I52(I) c), items v) and vii)). Once again, therefore, the EU regulation serves merely as a broad regulatory framework, leaving individual Member States the option of choosing the solution they deem better suited to their purposes and to the players involved.

Article 153 provides that the statutes of a PO must require its members to apply the rules adopted by the organisation in regard to production, marketing and environmental protection; be members, except in certain cases, of only one PO for each product; provide the information requested by the PO for statistical purposes; and pay the financial

${ }^{25}$ BlockX and VAndenberghe, «Rebalancing commercial relations along the food supply chain: the agricultural exemption from EU competition law after Regulation 1308/2013», in European competition journal, $2014,387 \mathrm{ff}$., in particular on page 398, the authors note that the majority of Member States had opposed making the recognition of all POs obligatory mainly because of concerns over the consequent administrative burden.

${ }^{26}$ The specific aims of POs in the milk and milk products sectors are set forth in Art. I52(3).

${ }^{27}$ The former Art. I22 of Regulation I234/2007 limited itself to the tasks of concentration of supply, adjusting production to market demands, optimising production costs and stabilising producer prices. 
contributions resolved on by the PO. The statutes must further establish penalties for those who infringe the rules adopted by the organisation or fail to pay the contributions due; be organised in such a way as to ensure that the PO is managed in accordance with democratic principles; and contain rules on the admission of new members and the minimum period of membership, which may not be less than one year. The recognition of POs, as provided for under Article 154, is conditional upon the PO being a legal entity and its fulfilment not only of the requirements concerning the activities to be carried out and the contents of the statutes, but also of those regarding the minimum number of members or minimum volume of marketable production, to be established by each Member State; it must also provide adequate assurances that it can carry out its activities properly. In relation to recognition, Article I54(4) assigns several tasks to Member States, including that of adopting measures to grant recognition within a well-defined time limit, carry out checks on recognised POs and apply adequate penalties in the event of verified non-compliance withdrawing recognition in the most serious cases - and informing the Commission yearly of the decisions to grant, refuse or withdraw recognition taken in the previous year.

As far as IOs are concerned, it may be noted first of all that the rules are more systematic and clearer than in the former regulation: in truth, a legislative framework of a general character is defined along with provisions of a special nature dedicated to IOs in certain production sectors. The general provisions include the requirement that an organisation's activities must embrace at least one of the objectives listed in Article I57(I)(c): these include improving knowledge and the transparency of production and the market, recording of public market prices, providing information for adjusting production, seeking ways to restrict the use of animal health products, and improving food safety and animal health and welfare ${ }^{28}$.

Among the special provisions, it is worth mentioning Article I62, which reiterates (given that the powers concerned were already granted under Article I23(I) of Regulation No. I234/07) that IOs in the tobacco sector and olive oil and table olives sector may have further tasks in addition to those of a regulatory nature ordinarily envisaged for such organisations, such as concentrating supply and marketing the products of members, adapting production and processing to market requirements, and promoting the rationalisation and improvement of production and processing.

Articles 158 and ${ }_{1} 6_{3}$ regard the recognition of IOs; the former lays down general rules, while the latter is dedicated specifically to IOs in the milk and milk products sector: among the requirements set forth, it is worth mentioning the fact that they must not engage in production, processing or marketing of the product ${ }^{29}$, with the exception, already noted, of IOs operating in the tobacco and olive oil and table olives sectors. In this case as well, specific tasks are entrusted to Member States; these are wholly similar to the ones established in relation to the recognition of POs.

${ }^{28}$ The former Art. I23 of Regulation No. I234/2007 established the activities that IOs in the olive oil and table olives and tobacco sectors can engage in and specified tasks similar to the ones now outlined in Art. I57; however, the previous regulation lacked any general rules concerning the tasks that could be carried out by IOs recognised in sectors other than the ones just mentioned, since the lists of tasks in paragraphs 3 and 4 of the former Art. I23 of Regulation No. 1234/2007 regarded solely IOs operating in the fruit and vegetables and wine sectors, respectively.

${ }^{29}$ Cf. Art. I58( I)(d) and Art. I63( I)(d). 
A novelty of no little importance is the provision granting Member States the option of extending, at the request of the PO or IO concerned, and for a limited period of time, certain rules set by the organisation and the provision concerning compulsory contributions, set forth in arts $\mathrm{I}_{4}$ et seq. of the new regulation. This applies for recognised POs and IOs in any sector (as well as for recognised associations of POs), provided that they are sufficiently representative in a given geographical area; more specifically, the regulation uses the expression «economic area», defining it - solely for the purposes of the procedure concerned - as a «geographical zone made up of adjoining or neighbouring production regions in which production and marketing conditions are homogeneous $»^{30}$. The requirement of being sufficiently representative is considered to be met if a PO accounts for $50 \%$ of producers in the economic area ${ }^{31}$ and, in the case of other organisations or associations, if it accounts for a percentage of the volume of production, trade or processing in the economic area equal to at least $2 / 3$, or $60 \%$ in the cases of POs in the fruit and vegetables sector. Finally, Article I64(4) contains a precise indication of the rules for which compulsory extension may be requested; in principle, such rules must not cause damage to other operators and cannot be incompatible with EU law or the law of the Member State concerned; in regard to anti-competitive practices, the extension must not produce any of the effects described in Article 2IO(4) of the same regulation (in particular, the aforementioned provision establishes that agreements, decisions and practices will be considered incompatible with EU law if they may lead to the partitioning of markets within the Union in any form; may create distortions of competition which are not essential to achieving the objectives of the CAP; entail fixing prices or quotas; may create discrimination or eliminate competition in relation to a substantial portion of the products in question).

Tied to the extension of rules is the option granted to Member States to establish after carrying out the necessary consultations with all stakeholders - that economic operators who benefit from the activities relating to the rules in question must pay the organisation which adopted the rules all or part of the financial contributions paid by its members «to the extent that such contributions are intended to cover costs directly incurred as a result of pursuing the activities in question» (as stated in Article I65).

As noted, this is not a complete novelty, since the provisions of the former Regulation No. I234/O7 - specifically, Articles I25f and I25l - envisaged this possibility, respectively for POs and IOs, though only in the fruit and vegetables sector: according to the current rules, however, this possibility is offered to organisations operating in any production sector, provided that they are recognised organisations considered duly representative as described above. This is consistent with the declared need to strengthen the role of POs and IOs.

It is of course necessary to verify the concrete application of these provisions, which are characterized by numerous conditions and requirements, as is moreover justified by the

\footnotetext{
${ }^{30}$ Thus stated in Art. I64(2).

${ }^{31}$ This solution can also be adopted for IOs in the event that it proves difficult to apply the criterion based on the volume of production: see Art. I64(3), second subparagraph.
} 
sensitive nature of the subject, since it implies that rules approved by private organisations will be binding for third parties ${ }^{32}$.

Besides a general rationalisation of the rules for organisations or associations involving only or also agricultural producers, and a general broadening of the activities they may engage in, the new legislative text in any case introduces (or rather, expands) some innovative solutions, which are added to the provisions governing associations, and consistently aim to achieve a more effective protection of the weak party in the contractual relationship. They will be discussed in the following section.

\section{III. (continued): possible formalisation through written contracts for the delivery of products falling within the scope of the CMO}

Article I68 of the new regulation lays down rules concerning «contractual relations» (as the heading states), and is likewise applicable to all of the sectors covered by the CMO, with the sole exception of the milk and milk products sector ${ }^{33}$ and sugar sector ${ }^{34}$; the exception, however, is only apparent because similar rules are defined for them in other articles.

The provision is not new, given that Regulation (EU) No. n. 26I/20I2 ${ }^{35}$ granted solely for the milk and milk products sector ${ }^{36}$ - Member States the power to impose obligations related to the content and form of contracts for the delivery of raw milk, by introducing Article I85f into Regulation (EC) No. I234/07. This article was dedicated, precisely, to contractual relations in that sector. It specified, however, that even if a Member State decided that such contracts must be in written form, the conditions set out in the regulation were in any case intended solely as a means of enhancing the transparency of the contract, as the legislative provision did not mean to impose any substantive requirements or compel compliance therewith. On the contrary, it expressly stated that the parties would be free to negotiate all elements of the contract, except where a minimum duration of six months has been provided for; in this case there was no possibility of derogation for the processor $^{37}$. The rule is noteworthy, however, because it established that if a Member State

${ }^{32}$ On this subject, insofar as Italian law is concerned, see BologniNI, «Il D. lgs. 27 maggio 2005, n. IO2 e l'attuale tendenza normativa a riconoscere efficacia ultra partes ai contratti di integrazione verticale in agricoltura», in La regolazione e la promozione del mercato alimentare nell'unione europea. Esperienze giuridiche comunitarie e nazionali, Proceedings of the Conference of Udine, 24-25 November 2006, Milan, 2007, $205 \mathrm{ff}$.

${ }^{33}$ The relevant rules are contained in Art. I48.

${ }^{34}$ The relevant rules are contained in Art. I25.

${ }^{35}$ Regulation (EU) No. n. 26I/20I2 of the European Parliament and of the Council of I4 March 20I2, amending Council Regulation (EC) No I234/2007 as regards contractual relations in the milk and milk products sector, in OJEU L 94, which was followed by Commission Implementing Regulation No. 5II/20I2 of I5 June 20II, and Commission Delegated Regulation No. 880/20I2 of 28 June 2012.

${ }^{36}$ Here an approximate date was set for the end of the quota system, which would be phased out by April 2015 , with consequent tensions on the prices of the raw material. For a recent report which identifies a series of factors that have to date prevented the increase in selling prices forecast - perhaps a bit too optimistically - by the EU Commission from taking place, see USDA, Foreign Agricultural Service, Dairy: World Markets and Trade, July 2015, in apps.fas.usda.gov/psdonline/circulars/dairy.pdf.

${ }^{37}$ It is worth noting that in view of the provisions of Regulation (EU) No. 26I/I2, both Italy and Spain decided to make written contracts compulsory (the Italian rule is moreover embraced in the more general provision of Art. 62, Law Decree no. I of 2012, which will be discussed further below), respectively with Ministerial Decree no. I5I64 of I2 October 2012, and the Royal Decree of 28 September 20I2, published in the Spanish Official Journal (B.O.E.) of 2 October 20I2. Art. I5 of the Royal Decree moreover prohibits the sale of 
were to avail itself of that option, the contract ${ }^{38}$ (written) would have to comprise a series of relevant elements - listed in paragraph 2 of the same article - making up overall provisions of the contract. These include: duration (which could also be indefinite), methods of collecting or delivering the milk and the terms of payment, the volumes agreed on under the contract, the price payable, which had to be set out expressly or calculated accordingly, it being understood that the contract would necessarily be concluded in advance of the delivery ${ }^{39}$. As noted, the provision (in paragraph 4 ) had taken care to specify that the content of the contract was freely negotiable ${ }^{40}$.

With the reform of 2013 , therefore, these rules, originally meant to be applied only in the dairy sector, came to apply more generally in all production sectors embraced by the CMO; however, their concrete implementation is once again left up to the Member States. After establishing that the delivery of any of the products covered by the CMO to a processor or distributor must be covered by a written contract (or that first purchasers must make a written offer), Member States will be obliged to extend formal constraints also to the clauses specified in paragraphs 4 and 6 of the same article, though the latter specifies that the content of the contract ${ }^{4 \mathrm{i}}$ shall always be freely negotiable, notwithstanding the option granted to Member States of establishing a minimum duration of at least six months.

In particular, if a Member State opts to make it compulsory to put such contracts (or offers for a contract) in writing, it must require that they be concluded in advance of delivery and specify the price to be paid to the farmer, which can be fixed and established in the contract, or calculated on the basis of factors likewise set out in the written contract, the quantity and quality of the products to be delivered, the timing of the deliveries, the

raw milk that is provided for under a contract for the delivery of milk concluded in violation of the obligation to formalise it in writing or the requirements as to it minimum contents; this provision that is hardly compatible with the principle of the free movement of goods within the European market, given that the constraints imposed on the contract regard all negotiated agreements involving a delivery of raw milk in Spanish territory (Art. Io of the R.D.).

${ }^{38}$ Deliveries made by a producer to a cooperative of which he was a member were not subject, in principle, to the requirements indicated in the text: in particular, this exception would apply only if the statutes of the cooperative contained provisions similar to the ones set out in paragraph 2 of Art. I8 $5 \mathrm{f}$.

${ }^{39}$ This is essentially an exemplary case (even if it relates to a contract concluded between business partners) of neo-formalism in the realm of negotiations, aimed at directly protecting the party who suffers from a lack of information and reduced bargaining power, as well as - indirectly - the structure of the target market: on this subject, see JANNARELLI, «La disciplina dell'atto e dell'attività: i contratti tra imprese e tra imprese e consumatori», in Trattato di dir. priv. europeo, a cura di LIPARI, Vol. III, L'attività e il contract, Padova, 2003, $48 \mathrm{ff}$. However, this is not an absolute novelty for European law; one need only consider what is established by Art. I3 of Directive 86/653/EEC on the coordination of the laws of the Member States relating to self-employed commercial agents (aptly pointed out by JANNARELLI, op. cit., I08), whereby each party (both businesses) «shall be entitled to receive from the other on request a signed written document setting out the terms of the agency contract including any terms subsequently agreed. Waiver of this right shall not be permitted», and Member States may provide that an agency contract «shall not be valid unless evidenced in writing». The provisions of Art. I85f certainly appear more analytical and apply right from the negotiating phase.

${ }^{40}$ Pursuant to Art. I85 f(4)2(i), a Member State may require that the contractual relationships have a minimum duration of six months; however, the farmer may waive the minimum duration where established by national law, provided that he does so in writing. The option of establishing a minimum duration seems to be intended as a provision favouring the seller, the only party entitled to waive it.

${ }^{41}$ On this subject (insofar as the milk and milk products sector is concerned), recital I27 states that Member States (in consideration of the principle of subsidiarity and the diversity of situations across the EU) may decide whether to make the use of written contracts compulsory in the absence of EU legislation on formalised contracts for the delivery of agricultural raw materials, provided that the proper functioning of the internal market is respected. However, in the milk and milk products sector, to ensure the proper functioning of the internal market and of the CMO, some basic conditions for the use of such contracts should be laid down at the Union level. Recital $\mathrm{s} 38$, on the other hand, addresses written contracts involving products other than milk. 
duration of the contract (definite or indefinite), termination clauses, if any, payment periods and procedures, arrangements for collecting and delivering products and the rules applicable in the event of force majeure. In any case, it is a list of clauses that goes beyond those that are essential for the existence and validity of a contractual agreement: listed alongside essential elements, such as the subject matter of the contract, there are provisions that, despite being of relevance within the overall framework of the contract, are not required in order for the latter to be valid.

As appears evident from the clarification that the elements contained in the contract (or offer) are freely negotiated between the parties, the main purpose of the article is to enhance (solely) the transparency of contractual provisions (at least the main ones within the framework of the contract); this is meant especially to ensure that the farmer, considered the weaker party of the relationship, will be able not only to have adequate information in advance (of the deliveries of the product) concerning the contractual content, but also to rely on a formalisation of the same, thereby avoiding, to the extent possible, potential unfair behaviour on the part of the purchaser ${ }^{42}$. Where contracts are concluded only verbally, the latter can better exploit his position of strength, by modifying the terms as needed or applying new conditions retroactively, knowing that the agricultural producer will have difficulty in reconstructing the original content of the contractual conditions for the difficulties in providing supporting evidence in the case of a verbal contract.

In reality, some minimal requirements for the compliance of contracts are provided for in Article 168, where Member States that have decided to introduce formal constraints for the contracts in question are granted the option of establishing a mandatory minimum duration of at least six months. The mandatory nature of this constraint is only relative and is solely to the advantage of the producer, since the latter must always be granted the right to refuse the minimum duration established by the Member State.

As regards the rule in question, it should be observed that, by leaving every decision concerning its application up to the Member States - assuming in the meanwhile that it is indeed applicable because the Member State autonomously decided to make written contracts for the delivery of products covered by the CMO compulsory - it is liable to be applied in a patchwork manner across the EU. Such a situation can certainly not be considered conducive to the proper functioning of the internal market; one need only consider that where written contracts are made compulsory, the obligation will apply for all contracts involving agricultural products whose delivery will take place in the Member State concerned, even if one of the parties is of a different nationality. It is thus clear, for example, that a same purchaser who concludes business transactions with agricultural producers operating in a number of different Member States, receiving the products he purchases in the territory of those States, may find himself subject to different contractual rules precisely because of a provision of EU law. Hence it is not difficult to imagine that, in the absence of a strong harmonised framework, stronger enterprises may attempt to elude the regulatory provisions of a neo-formalist type by contracting with producers operating in Member States that have not implemented the EU provisions, or else by stipulating that the

${ }^{42}$ On the effectiveness of transparency - in respect of the content of contractual provisions - for the purpose of facilitating the weak contracting party, see FAVALE, «Il formalismo nel diritto dei consumatori», in Contr. impr. Europa, 2012, 582 ff.; AlPA, Le stagioni del contratto, Bologna, 20I2, I4I ff. 
product to which the contract relates be delivered to a location outside the territory of the State or States that have introduced the rule on written contracts.

Therefore, the provision contained in paragraph 7 of Article 168, whereby Member States must in any case ensure that the rules they implement on the basis of the latter do not impair the proper functioning of the internal market, appears to be nothing more than a merely formal statement, given that it is the very structure of the provision itself which enables a non-uniform application across the territory of the $\mathrm{EU}^{43}$.

Ultimately, the legislation in question achieves a sort of optional harmonisation of very limited scope as it establishes only that the requirement of formalisation in writing, if and to the extent determined by each Member State in a wholly autonomous manner, must also extend to the main provisions of a contract in order to increase the level of awareness of the weak party in respect of the contractual terms and conditions, and that the contract, to be drawn up in writing, must necessarily be concluded prior to the delivery or deliveries of the product; the parties are free to decide on the concrete terms of the contractual relationship, with the sole exception - again left up to the discretion of each Member State - being the possible introduction of a minimum duration as a mandatory condition for the purchaser ${ }^{44}$.

The provisions of Regulation No. 1308/2013 say nothing in regard to the consequences of a failure to fulfil the written contract obligation established by a Member State or to include the minimum information required by the regulation in the text of the contract, or of a violation of the minimum duration imposed on the purchaser: therefore, the application of penalties is also left to the discretion of Member States. The result is a further fragmentation of legislation, since the latter can establish remedies or penalties that may differ considerably in entity, as well as vary in nature (e.g. civil versus administrative sanctions) $)^{45}$.

It is worth observing, moreover, that even before the introduction of Regulation No. I308/2013 several European countries ${ }^{46}$ had already approved legislation with substantially

\footnotetext{
${ }^{43}$ Pursuant to the same paragraph 7, Member States are also required to notify the Commission about any measure adopted under Article i68.

${ }^{44}$ In the Communication from the Commission to the European Parliament, the Council, the European Economic and Social Committee and the Committee of the Regions, Tackling unfair trading practices in the business-to-business food supply chain, issued on 15.7.2014, COM (20I4) 472, it is reported that 96\% of respondents to an EU-wide survey among suppliers in the food supply chain affirmed that they had been subject to at least one form of unfair trading practice. Despite this, there is nothing in the aforesaid Communication to suggest, at least for the time being, that the Commission intends to promote a legislative initiative on a European level to combat the abuse of bargaining power in business-to-business dealings, though the Commission acknowledges the extreme diversity of the approaches adopted by some Member States in dealing with the issue, noting that «where [national] regulations do exist, they differ in terms of the nature, level and legal form of protection provided against UTPS».
}

${ }^{45}$ In certain respects it is surprising that the regulation contains no provision for penalties, since the Commission has on various occasions addressed the topic of unfair trading practices in the food supply chain, as well as the regulatory fragmentation in this area. Essentially, all decisions are left to the discretion of the individual Member States, including those regarding sanctions, which differ from State to State, resulting in a «high degree of divergence in terms of the level, nature and legal form of protection provided against UTPs at the national level», which implies a fragmentation of the single market: see, for example, Green Paper of the European Commission on Unfair Trading Practices in the Business-to-Business Food and Non-Food Supply Chain in Europe, issued on 31.I.2013, COM (2013) 37.

${ }^{46}$ And not only: even in the United States, for example, some first timid steps are being made in this direction: see SIRSI, I contratti del mercato agro-alimentare: l'esperienza USA, in Riv. dir. alim., n. I/20I3, 40 ff. 
analogous content: these include Italy, with Article 62 of Law Decree no. I of 2012 ${ }^{47}$; Spain, with Law no. I2/20I3 concerning the food supply chain ${ }^{48}$; and France, with a law on modernisation of agriculture and fisheries issued on 27 July $2010^{49}$.

As regards Italy, pursuant to Article 62, Law Decree no. I of 2012 (converted, with amendments, into Law no. 27 of 20I2), the contracts concluded between agricultural producers and processors or distributors for the delivery of the agricultural products listed in annex I TFEU (as well as food products as per Regulation (EC) No. I78/2002 $2^{50}$, again in business-to-business contracts) were already required to be in written form and have a minimum content in terms of the contractual provisions set out therein; this regulatory requirement was backed by administrative penalties. However, if we take a closer look, the scopes of application of the two pieces of legislation do not coincide completely, since Article I68 (together with Articles I25 and I48) is intended to apply only for the products subject to Regulation No. 1308/2013 (and specified in Article I of the same regulation), whereas Article 62 of the Italian Law Decree - as amended by the implementing ministerial decree $^{5 \mathrm{I}}$ - extends the scope of application to deliveries of all the agricultural products listed in Annex to the TFEU, as well as the food products specified in Regulation (EC) No. I78/2002: suffice it to say that Regulation No. I308/2013 does not apply to fishery and aquaculture products, which are included, by contrast, in Annex I, and that the range of food products defined by Regulation $178 / 2002$ is much broader than the one governed by the provisions of Regulation (EU) No. n. 1308/2013.

Moreover, Italian legislation does not appear to be particularly clear as to whether the rules apply only to supply contracts that will remain in force for a given period of time, or also apply to contracts without a duration. Nor does it specify whether the written contract must be concluded in advance of the delivery or deliveries of the product. The domestic law contains no indications regarding the inclusion of termination clauses among the written contractual provisions, or, more generally speaking, cases in which a contract

${ }^{47}$ On contracts for the delivery of agricultural and food products pursuant to Art. 62, of Law Decree no. I of 2012 , converted into Law no. 27 of 20I2, recently amended by Art. 2 of Law no. 9I of 2 July 2015 converting Law Decree no. 5I of 5 May 20I5; see Albisinni, «Cessione di prodotti agricoli e agroalimentari (o alimentari?): ancora un indefinito movimento», in Riv. dir. alim., 20I2, n. 2, 33 ff.; ARTOM, «Disciplina delle relazioni commerciali in materia di cessioni di prodotti agricoli e agroalimentari», ibidem, 42 ff.; GERMANÒ, «Sul contratto di cessione di prodotti agricoli e alimentari», in Dir. giur. agr. alim. amb., 20I2, 379 ff.; TommASinI, «La nuova disciplina dei contratti per i prodotti agricoli e alimentari», in Riv. dir. alim., 20I2, n. 4, 3 ff.; JANNARELLI, «La strutturazione giuridica dei mercati nel sistema agro-alimentare e l'art. 62 della legge 24 marzo 20I2, n. 27: un pasticcio italiano in salsa francese», in Riv. dir. agr., 20I2, I, 545 ff.; TURIN, «La nuova disciplina dei contratti e delle relazioni commerciali di cessione dei prodotti agricoli e alimentari», in Contr. e impr., 20I3, I425 ff.; sia altresì consentito il rinvio a Russo, «I contratti di cessione dei prodotti agricoli e alimentari (e quelli di cessione del latte crudo): nuovi tipi contrattuali per il mercato agroalimentare?» in Le nuove leggi civ. comm., 20I3, I99 ff.; ID., I nuovi contratti agrari, cit. Concerning the former legislation, see TAMPONI, «Contratti di subfornitura e contratti agro-industriali: due leggi a confronto», in Scritti in onore di E. Romagnoli, Milan, 2000, II, I303 ff.

${ }^{48}$ Ley I2/20I3 of 2 August 2013 de medidas para mejorar el funcionamiento de la cadena alimentaria; see A. SANCHEZ HERNANDEZ, «Los contratos alimentarios en la Ley de la cadena alimentaria. (Referencia a la normativa y doctrina italiana 'dei contratti di cessione dei prodotti agrícola e agroalimentari'», in Actualidad Civil, 3/2015, from 4 to 35 .

${ }^{49}$ Law 20Io-874 of 27 July 2010 de modernisation de l'agriculture et de la peche; see C. DEL CONT, «Filères agroalimentaires et contrat: l'expèrience francaise de contractualisation des relations commerciales agricoles», in Riv. dir. alimentare, n. 4/2012, I ff.

${ }^{50}$ Regulation (EC) No. I78/2002 of the European Parliament and of the Council of 28 January 2002, laying down the general principles and requirements of food law, establishing the European Food Safety Authority and laying down procedures in matters of food safety.

${ }^{51}$ Ministerial Decree no. I99 of I9 October 20I2, in Official Gazette no. 274 of 23.II.20I2. 
may be cancelled (despite the fact that provisions concerning the possible withdrawal from a contract are of fundamental importance for the party in a disadvantaged position) or the provisions applicable in the event of force majeure, which are instead provided under the EU regulation. It should also be pointed out that Article 62 does not intervene directly in respect of the contract's compliance with formal requirements; it is only concerned with the transparency of the elements that must be formalised in writing, despite containing a number of references to the requirement that the contract for the delivery of agricultural or food products be «fair» ${ }^{52}$. By contrast, Italian legislation implementing the provisions of Article I85f, Regulation (EC) No. $1234 / 07^{53}$ and, at a later time Article I48, Regulation No. I308/201 $3^{54}$, concerning the formalisation in writing of contracts for the delivery of raw milk, on the one hand defers - as regards the obligation to use written contracts - to the provisions of Article 62 of Law Decree no. I of 2012 as the highest ranking legislation to be applied in generalised fashion to all contracts for the delivery of agricultural products listed in Annex I to the TFEU; but on the other hand, it adds that such contracts must be concluded in advance of delivery and contain all of the elements specified in the referenced EU legislation and that the minimum duration of the contracts in question is now twelve months, unless the supplier refuses this duration.

The Spanish law similarly seems to have a vaster scope of application than Article I68 of Regulation No. I308/2013; in fact, it applies to all trade relations among food supply chain operators engaged in the production, distribution and processing of food products not only of the agricultural products covered by the single CMO. In other respects, however, the Spanish law seems to narrow the scope of application compared to EU provisions, since Title II of the law - which contains rules concerning the form and minimum content of contracts - is applicable solely to contracts that set delivery prices above $€ 2.500$ and contain at least one of the following elements: a) one of the parties is an SME, and the counterparty is not; b) in the event of delivery of non-processed agricultural products, one of the parties is a farmer or fisherman or an association of farmers or fishermen and the counterparty is not; c) one of the two parties is in a position of economic dependence on the other, i.e. a situation in which the dependent enterprise, in relation to the product to which the contract relates, earned at least $30 \%$ of its overall revenue from the other party in the previous year. Under the aforesaid law such contracts must: i) be concluded in writing prior to start-up of the deliveries provided for thereunder, it being specified, however, that the written form is

${ }_{52}$ See the last part of paragraph I, whereby contracts must be based on principles of transparency, correctness, proportionality and correspondence between the goods supplied and the consideration received, as well as paragraph 2, which prohibits, in principle, some behaviours deemed substantially abusive or unfair. As regards unfair trading practices, it may be noted that Art. 7 of Law Decree no. I of 20I2, converted into Law no. 27 of 20I2, extended the scope of applicability of the relevant rules to embrace - though not in their totality unfair trading practices between a professional and micro enterprises (as defined in Commission Recommendation 2003/36I/EC of 6 May 2003), with a consequent amendment of articles I8 et seq. of the Consumer Code (Legislative Decree no. 205 of 2006): for a discussion of the resulting problems, see DE CRISTOFARO, «Pratiche commerciali scorrette e 'microimprese'», in Le nuove leggi civ. comm., 2OI4, $3 \mathrm{ff}$.

${ }^{53}$ Ministerial Decree no. I5I64 of 12 October 2012

${ }^{54}$ Cf. Art. 2 of Law Decree no. 5I of 5 May 20I5, as converted by Law no. 9I of 2 July, 20I5, published in the Official Gazette no. I52 of 3 July 20I5. While Ministerial Decree no. I5I64 of 2012 implementing Art. I85f of Regulation (EC) No. I234/O7 established a minimum duration of six months, the subsequent law 91/2015 increased the duration to twelve months, a period deemed to be more in line with farmers' demands for protection; however, in this case as well, the latter may waive the minimum duration provided that they do so in writing. Art. 2 of Law no. 91/20I5 establishes in any case that the provisions set forth in Art. I4 8 of Regulation No. $1308 / 2013$ are applicable to contracts for the delivery of raw milk, including, therefore, the requirement that the contracts be concluded in advance of the delivery and contain all the contractual elements listed therein. 
not required in order for the contract to be valid and that the rule does not apply in cases in which the payment of the price takes place at the time of delivery del product ${ }^{55}$; ii) contain a series of minimum elements, namely, an identification of the parties; subject matter of the contract; price agreed on, fixed or anchored to elements that must be objective, verifiable, not manipulable and expressly mentioned in the text of the contract; terms of payment; method of delivery of the products; rights and obligations of the parties; sensitive information; duration of the contract, and the conditions for its renewal or amendment; and effects of the termination of the contractual relationship ${ }^{56}$. The Spanish legislator, like his Italian counterpart before him, provides for pecuniary administrative penalties in the event of failure to fulfil the obligations with respect to the written form and minimum content, such penalties being proportionate to the seriousness of the breach ${ }^{57}$.

Finally, as regards the French experience, the previously mentioned law on the modernisation of agriculture and fisheries (Law no. 20I0-874) had already amended some provisions of the Rural Code by introducing the possibility of concluding written contracts for the delivery of agricultural products, once this obligation had been provided for under an approved interbranch agreement or a decree of the Council of State; in such a case, the written contracts had to be in conformity with the standard supply chain contracts made compulsory by decree or as a result of approval or extension of the validity of an interbranch agreement. In this case as well, failure to comply with the obligation to draw up contracts in writing is punishable by means of a pecuniary administrative penalty (see Article L 63I-25 of the Rural Code). Article L 63I-24 of the Rural Code, finally, was recently amended - together with numerous other provisions of the Code - following the entry in force of Law 20I4-II7O of I3 October 20I4 $4^{58}$; however, there were no substantial innovations in respect of the above-mentioned points.

\section{IV. (continued): power to engage in contractual negotiations attributed to some POs under Regulation (EU) No. 1308/2013.}

As mentioned previously, the new regulation, in articles I69, I70 and I7I, grants some POs (or their associations) - and in particular those operating in the olive oil and beef sectors, as well as those representing producers of the arable crops listed in Article I7I (and milk and milk products sector under Article $149^{59}$ ) the power to engage in «contractual negotiations» (as per the heading of the cited articles).

\footnotetext{
${ }^{55}$ see Art. 8 of the law.
}

${ }^{56}$ As provided in Art. 9 of the law, under the heading of «contractual conditions».

${ }^{57}$ Cf. Art. 23 et seq. of the law.

${ }^{58}$ Loi d'avenir pour l'agriculture, l'alimentation et la foret; see the Dossier published in Revue de droit rural, $2 / 2015$, I5 ff.. The law was also intended to adapt French legal framework to the regulatory changes resulting from the 2013 reform of the CAP.

${ }^{59}$ On this subject, see recital 207 , which explains that the rules provided for the milk and milk products sector with respect to contractual relations and negotiations should be considered temporary in nature and subject to review. 
In this case as well, the rules are substantially similar to those introduced with Regulation (EU) No. 26I/I2 specifically for the milk sector ${ }^{6 \circ}$, despite the shortcomings already clearly noted ${ }^{6 \mathrm{r}}$. Moreover, the issues that had previously been raised with regard to the rules governing contractual negotiations in the milk and milk products sector were left completely unresolved ${ }^{62}$.

Under the aforementioned provisions, the POs in the sectors considered (or their associations: see paragraph 3 of the articles in question) that pursue such aims as concentration of supply, placing on the market of the products produced by its members, or optimisation of production costs, can «negotiate», on behalf of members, in relation to all or part of their production, the content of future contracts for the delivery of their respective products. The articles in question make this power subject to the condition that the negotiating activity leads to an integration of activities and that as a result it is probable that significant improvements will be made in the efficiency of the system, so that such activity of the POs contributes to attaining the objectives of the CAP as per Article 39 TFEU.

The negotiations can take place whether or not the ownership of the agricultural products considered is transferred by the farmer members to the PO, and whether or not the price that is negotiated is the same as for the joint production of all members of the PO or only part of them (as per points (a) and (b) of paragraph 2 of the articles in question).

The negotiations cannot regard volumes of products exceeding the percentages established for each product in the articles concerned (see paragraph 2 (c)); however, according to paragraph 5 , if the negotiations are such as to exclude competition or undermine attainment of the objectives of Article 39 TFEU, irrespective of whether the thresholds are exceeded, the national competition authority (or the Commission, if the negotiations involve more than one Member State) may, based on the concrete circumstance, decide that the negotiations must be reopened or cannot take place.

The producers concerned cannot be members of other POs that carry out similar negotiations (as per paragraph 2(e) of Articles I69, I70 and I7I).

The POs must notify the respective Member States of the volume of products to which the negotiations relate (paragraph 2(g) of the cited articles), and Member States in turn must notify the Commission of the data received from the POs or the intervention of the competition authority (paragraph 6 of the cited articles).

\footnotetext{
${ }^{60}$ On the origins of the provisions of Regulation 26I/20I2, see CHAUVE, PARERA, RENCKENS, «Agriculture, food and Competition law: moving the borders», in Journal of European Competition Law \& Practice, vol. 5, 2014, $309 \mathrm{ff}$.

${ }^{61}$ See JANNARELLI, «L'associazionismo dei produttori agricoli ed il «tabù» dei prezzi agricoli nella disciplina europea della concorrenza. Considerazioni in materia di latte e prodotti lattiero-caseari», in Riv. dir. agr., 20I2, I, I79 ff.

${ }^{62}$ Regulation 26I/I2, in particular, incorporated Art. I26c into Regulation I234/07; under this provision, recognised POs in the milk and milk products sector (or groups of such organisations) may negotiate, on behalf of members, in respect of all or part of their overall production, the terms of subsequent contracts for the delivery of raw milk by individual farmers to processors: and thus, presumably, to conclude standard contracts, which, being concluded by organisations representing a group of producers (thus endowed with greater bargaining power than a single farmer), should contain provisions less disadvantageous to farmers than would be the case if negotiations were decentralised and conducted individually.
} 
As noted, the aforementioned provisions raise numerous questions ${ }^{63}$. Firstly, it is not clear why the provisions make the power to engage in negotiations conditional on the fact that the POs in the sectors concerned already pursue the aim of concentrating the supply of their members, placing on the market of the products received from the latter. It is difficult to understand the purpose and usefulness of giving such contract negotiating powers to POs that already carry out activities of direct marketing, selling the aggregate production of their members directly to purchasers and thus acting as the sole contractual counterparty of the latter. From an abstract perspective, the POs in sectors in which contractual negotiations are an option can decide to directly concentrate production, selling the products of members in their own name and on their own behalf after receiving them; or else they can decide to limit themselves only to indirect concentration activities, negotiating, precisely, on behalf of their members, the best contractual conditions to be subsequently applied to contracts concluded on an individual basis.

However, it seems difficult to imagine that a same PO can engage both in an activity of direct marketing and an activity of only negotiating on behalf of its members: direct marketing activity requires the presence of an organisation and facilities of a certain size, which could not be justified in the case of a mixed - as it were - activity not entirely dedicated to direct marketing, as the investments necessary for that purpose would not be amortised.

The reference to such tasks as concentration of supply and placing members' products on the market should probably be interpreted in a broad sense, i.e. the aim is to grant the power of carrying out contractual negotiations to POs whose statutes envisage the option of concentrating supply, which can take place in two ways: directly, so that the PO is the seller and operates in its own name and on its own behalf, having procured the products made available by its members; or only indirectly, through the conclusion of framework agreements, i.e. contracts that do not entail a transfer of ownership, but rather whose purpose is to establish terms and conditions that will be binding for purchasers, and from which members may benefit, as negotiations conducted by a PO on behalf of all its members can undoubtedly lead to more favourable terms than negotiations carried out by a single producer.

In either case, empowering POs to engage in contractual negotiations ${ }^{64}$ seems a quid minus compared to the possibility, already provided for under European legislation, of directly marketing the products of members, thereby achieving what is no less than a concentration of supply ${ }^{65}$ : in fact, negotiations carried out by a producer organisation can be considered only an indirect concentration of supply, which is undertaken directly by

\footnotetext{
${ }^{63}$ On the new rules, see JANNARELLI, «'Agricoltura e concorrenza' o 'concorrenza e agricoltura'? Gli artt. I69, I70 e I7I del reg. n. I308/20I3 e il progetto di guidelines presentato dalla Commissione», in Riv. dir. agr., 20I5, I, $3 \mathrm{ff}$.

${ }^{64}$ The role ascribed to POs by the provisions concerned is positively viewed by ALBISINNI, La nuova OCM ed $i$ contratti agroalimentari, in I contratti del mercato agroalimentare, a cura di Albisinni, M. Giuffrida, Saja e Tommasini, Naples, 2013, 69 ff.; see also ID., Intervento, op. cit., I99 ff., in which the author talks about a «rediscovery of the contractualization of relations on a European level».

${ }^{65}$ Under Art. I52(I)(c)(ii) of Regulation No. I308/I3, the POs recognised in the sectors considered by the article itself (including those operating in the milk and milk products sector) can concentrate supply and directly market the production of members.
} 
individual agricultural producers with the counterparties on the basis of negotiations previously conducted by the representative organisation ${ }^{66}$.

Moreover, as was observed earlier, the negotiating power is subject to a series of limitations that do not apply in the case of direct marketing. In addition to the restrictions regarding the maximum market percentages that can be covered by negotiations in the sectors considered $^{67}$, the rules require, as has already been mentioned, that the contractual negotiations lead to an integration of activities and that this integration is likely to generate significant gains in efficiency ${ }^{68}$. Based on a reading of the provisions, in truth, it does not appear to be sufficient, for the POs concerned, to carry out negotiations, a quid pluris being required on the part of the same, since they have to carry out at least one of the following activities: joint distribution, joint promotion (solely for the live cattle and arable crop sectors), joint organising of quality control, joint use of equipment or storage facilities, joint management of waste directly related to the production of olive oil or live cattle, joint procurement of inputs and joint processing of olive oil ${ }^{69}$.

A useful tool for interpreting the provisions in question might come from the guidelines that the Commission is drafting for the purpose of providing specific indications to the producers involved, particularly as regards defining the requirements laid down by the provisions themselves with respect to the integration of activities and significant improvements in efficiency that should ensue from the negotiations; at present, a simple draft version of such guidelines is available ${ }^{70}$; it has been published to enable public consultation on this topic, while the final version is expected to come out at the end of 2015 .

However, a reading of the draft reveals that the subject of contractual negotiations is far from having received any actual clarification, since the guidelines provided do not seem to distinguish clearly between the two cases described above, namely, direct concentration of supply and indirect concentration of supply, the latter taking place through the conclusion of framework agreements or collective agreements negotiated by POs. On the contrary, as already highlighted by legal scholars who have examined $\mathrm{it}^{\mathrm{T}^{1}}$, the draft sometimes seems to confuse the two cases or treat them as one and the same thing: we need only consider, for example, that in paragraph (4) of the introduction it is acknowledged that articles 169 to I7I authorise POs in the sectors concerned to negotiate, «on behalf» of their members, contracts for the supply of the products in question; further

${ }^{66}$ Cf. Chauve, Parera, Renckens, Agriculture, food and Competition law: moving the borders, cit., 3Io; the authors point out that through the agreements in question, POs sell «on behalf» of member producers, provided that the organisations engage in other joint activities connected to selling activity: «in practice this means that, when farmers wish to negotiate contract terms collectively via POs to gain bargaining power, they are obliged to integrate other activities in order to respond to market challenges in a pro-competitive manner». However, shortly afterward the same authors observe that the new legislation has introduced the concept of efficiency as a prerequisite for enabling «horizontal agreements between farmers»: in the case in question, however, it is not a matter of horizontal agreements among agricultural producers, but rather vertical agreements concluded between POs, on the one hand, and purchasers on the other.

${ }^{67}$ Equal to $20 \%$ in the olive oil sector, $15 \%$ in the live cattle sector and $15 \%$ in respect of the arable crops listed in Art. I7I; as provided in Paragraph 2(c) of the articles considered.

${ }^{68}$ see Paragraph I(2) of the articles considered.

${ }^{69}$ as per Paragraph I(3) of the articles considered.

${ }^{70}$ Communication from the Commission, Guidelines on the application of the specific rules set out in articles 169, 170 and 171 of the CMO regulation for the olive oil, beef and veal and arable crops sectors, Draft 2015.

${ }^{71}$ see JANNARELLI, op. ult. cit. 
below, in paragraph (13) it is specified that POs, for the purposes of EU competition law, can be considered as associations of undertakings and as an undertaking in their own right, if and to the extent that they conduct, on their own behalf, an economic activity, i.e. an activity involving the supply of goods or services in a given market. In this manner the Commission acknowledges to be fully aware of the possible double role that POs can play in the market, since they can operate as associations and thus negotiate on behalf of their members, or else operate as businesses, marketing the products contributed by their members. Consistently with this notion, paragraph (24) states: «Articles I69, I70 and I7I of the CMO Regulation thus concern any agreements or decisions or practices taken by the PO when negotiating contracts for supply on behalf of its members».

Against this initial background, a reading of the rest of the draft arouses a number of doubts as to the scope the Commission wishes to attribute to the provisions in question: paragraph (27) states that the purpose of the specific articles concerned is to be achieved through «POs effectively concentrating supply and placing products on the market and, as a consequence [my emphasis], negotiating supply contracts on behalf of their members»; similarly, in paragraph 58) one reads that the POs concerned must «pursue at least one of the following objectives of concentrating supply, placing on the market of the products produced by its members; and optimising of production costs» ${ }^{72}$. Moreover, the Italian text includes references to contracts concluded a nome (literally, «in the name») of members and per conto («on behalf») of members, with the expressions used apparently interchangeably.

However, the Commission made no effort to provide any indications as to how the conducting of contractual negotiations on behalf of members can coexist with pursuit of the objectives of concentrating supply and placing members' products on the market, where the PO acts in its own name and on its own behalf. Not only: notwithstanding the fact that, as we have seen, in paragraph (58) the draft guidelines acknowledge that in order to be able to engage in negotiations the POs must pursue at least one of the specified objectives (concentrating supply, placing on the market of the products produced by its members, and optimising of production costs), in the very next paragraph the Commission clarifies that, in actual fact, a PO that pursues solely the objective of optimising production costs will not be entitled to engage in contractual negotiations: this may very well go beyond the intended meaning of the provisions concerned, which do not seem to support such an affirmation.

Therefore, it is in some respects paradoxical that the Commission's guidelines, which are supposed to guide operators and ensure a uniform, correct interpretation of the regulatory provisions, contain a series of ambiguous affirmations, such as to raise doubts about the scope of the new legislation ${ }^{73}$ : it is thus to be hoped that following the period of public consultation, the final document will be more intelligible and, above all, clearly

\footnotetext{
${ }^{72}$ For a critical view on the Commission's breakdown of objectives into three, where the concentration of supply is separated from placing on the market of the members' products, see JANNARELLI, «Agricoltura e concorrenza' o 'concorrenza e agricoltura'?... », cit., 59.

${ }^{73}$ Cf. JANNARELlI, «'Agricoltura e concorrenza' o 'concorrenza e agricoltura'?... », cit., 63; according to the author, given the ambiguities of the articles of the regulation, together with the equivocal indications contained in draft guidelines prepared by the Commission, there is a risk that articles 169 to I7I will be considered applicable not only to collective structures that perform a simple role of intermediation in negotiating contracts on behalf of their members, but also to those that actually concentrate the supply and sell the products they have acquired from members through a transfer of ownership; in such a case, the latter will also be subject to the requirements laid down by the articles considered; on this point, see also, $75 \mathrm{ff}$.
} 
define the differentiations that exist between the activity of direct marketing carried out by POs in accordance with regulatory provisions and the activity of negotiation conducted by the same organisations.

Among the provisions that are difficult to interpret, we may also include paragraph 2(a) of Articles I69, I70 and I7I $\mathrm{I}^{74}$, according to which negotiations by the PO may take place whether or not there is a transfer of ownership of the agricultural products by members to the PO: the rule, therefore, is that contractual negotiations can also be carried out by a PO after it has acquired ownership of the products received from member producers. However, it is not clear why a PO that has become owner of the products to be marketed should only engage in a pre-contractual negotiating activity (or conclude a framework contract) rather than directly marketing the product it is now owner of to purchasers ${ }^{75}$.

Furthermore, the legislation does not contain any provision as to which effects the outcome of the negotiations will have for the parties; this aspect concerns not so much the members of the PO - since the fact of belonging to the association in itself implies compliance with what the latter has committed to - as the contractual counterparties, given that the scope of application of a framework contract resulting from negotiations conducted by the PO on behalf of members cannot but be limited solely to the undertaking or undertakings involved during the negotiation stage ${ }^{76}$. There is no indication, in fact, as to the consequences of a deviation of an individual contract from the provisions of the collective agreement or the possible remedies available to the affected party.

In short, the rather muddled - to put it mildly - nature of the provisions considered clearly suggests that they are a product of compromise. Among other things, the receptiveness of the EU legislator to the idea of contractual negotiations being carried out by organisations and associations of agricultural producers touches a raw nerve in EU legislation, in particular as it seems in contradiction with the rule - dating back to 1962 and left untouched even after the reform of 2013 - whereby such organisations may not establish identical prices binding for their members.

As will be amply discussed in the section that follows, there is no doubt that the contractual negotiations carried out by POs can also establish the subsequent selling prices and that, as a consequence, the legislation in question has for the first time expressly addressed what has been referred to, precisely, as the «taboo» issue of prices ${ }^{77}$.

\footnotetext{
${ }^{74}$ Similar considerations apply for Art. I49(2)(a) of Art. I49, Regulation No. 1308/2013, which specifically regards the dairy sector.

${ }^{75}$ On this point, see JANNARELLI, «Agricoltura e concorrenza' o 'concorrenza e agricoltura'?... », cit., 57; according to the author, negotiations make sense only in situations where ownership of the products is not transferred to the organisation. In the event of a transfer of ownership, there would be no reason for the organisation to conduct negotiations on behalf of its members; it would negotiate with third parties and sell the products its members have pledged to contribute within the framework of the organisation; for a previous discussion, see JANNARELLI, «L'associazionismo dei produttori agricoli ed il tabù dei prezzi agricoli nella disciplina europea della concorrenza», cit., 200; the same author seems to draw confirmation from the text of the provision that the entirety of the rules concerning «negotiations» is nothing else but a confirmation of the direct marketing power ascribed to the POs by their members; paradoxically, this power would be decreased with respect to the majority of cases, given the restrictions imposed by the provision.

${ }^{76}$ The effectiveness of a contract may be extended to the benefit of producers who are not members of the PO that has negotiated it under the provisions of Art. I64 ff. of Regulation No. I308/20I3, to the extent that this is concretely possible.
}

77 Again see JanNARELli, «L'associazionismo dei produttori agricoli ed il tabù dei prezzi agricoli nella disciplina europea della concorrenza», cit. 
Therefore, the ensuing result, with all its contradictions and ambiguities, should not be surprising. Numerous indications of such contradictions have come not only from the different European institutions involved in the legislative procedure, but also - and above all - among the different levels or departments of the same. Here there is a clear reference to the ever enduring conflict within the Commission between the Directorate-General called upon to apply and oversee the enforcement of competition rules and the DirectorateGeneral responsible for planning initiatives with the framework of the CAP.

The result of this internal dialectic is there for everyone to see: provisions containing references that are uncertain or confused to say in the least and which risk undermining their actual effectiveness. As has often been the case with other legislative provisions, articles I69 to I7I, together with article I49 for the dairy sector, are likely to represent only a first - and inadequate - approach to the subject matter. They will hopefully receive full implementation over time, once the initial disconcertment and scepticism have been overcome. We must therefore hope that the EU legislator will go back to review the provisions in question as soon as possible, so as to more precisely clarify their scope and content, attenuating the precautions provided for and in any case extending their application to all sectors of the CMO.

\section{Antitrust rules in Regulation (EU) No. 1308/2013 and their inadequacy for the purposes of protecting agricultural producers vis-à-vis the market.}

A report dealing with contracts, including collective contracts, in the agricultural and food product supply chain cannot neglect to include some brief considerations concerning the relationship between the rules governing supply contracts and agricultural associations and EU competition law, in particular as regards the specific antitrust provisions applicable to the agricultural sector following the reform of 2013 .

In particular, as regards the agricultural products covered by the CMO, the special rules (derogating from the general ones contained in the TFEU) designed to protect competition are contained in Part IV of Regulation (EU) No. 1308/2013 (Articles 206 to $2 \mathrm{I} 8)^{78}$, as well as in Article 222, which, among the general provisions in Part V, falls within the «exceptional measures» defined in Chapter I. As a result, the Commission can declare the temporary non-application of Article IOI(I) TFEU to some types of agreements and decisions of recognised POs, associations of POs, and IOs «during periods of severe imbalance in markets», provided that they do not impair the proper functioning of the internal market and are exclusively aimed at stabilising the affected sector.

Therefore, it is necessary preliminarily to describe, albeit briefly, and to the extent that it is useful for the purposes of this paper, how the relevant legislation is presently structured; this summary analysis must be limited to the rules concerning behaviours of business undertakings; without considering, therefore, the rules concerning state aid, contained in Article 2II et seq.79. It must also be noted that Part IV of Regulation No. I308/20I3 is applicable to products falling within the scope of the CMO, whereas rules

\footnotetext{
${ }^{78}$ For a discussion of the former legislation, as per Art. I75 et seq. of Regulation (EC) No. I234/2007, see JANNARELLI, «Commento agli art. I75-I79, e CoSTATO, Commento agli art. I80-I82», in Il regolamento unico sull'organizzazione comune dei mercati agricoli, a cura di Costato, in Le nuove leggi civ. comm., 2009, I8I ff.

${ }^{79}$ Chapter IV contains no specific rules concerning abuse of dominant position.
} 
concerning the other remaining agricultural products are laid down in Regulation (EC) No. II $84 / 2006^{8 \circ}$. The latter was in turn recently amended following the adoption of Regulation (EU) No. $1379 / 2013^{8 \mathrm{r}}$ on the common organisation of the markets in fishery and aquaculture products: Article I of Regulation No. II84/2006 now clarifies, in fact, its own non-applicability not only for the products covered by the single CMO, but also for those falling within the scope of Regulation No. I379/2013 (i.e. the in fishery and aquaculture products listed in the annex to the Regulation itself, which lays down the pertinent competition rules in Article 40 et seq.).

Reiterating what was already provided for in the former legislation, Article 206(I) of Regulation No. I308/20I3 establishes that, in principle, article IOI et seq. TFEU shall apply to all agreements, decisions and practices referred to in Article IOI(I) and Article IO2 TFEU which relate to the production of, or trade in, agricultural products, unless otherwise provided in the Regulation itself. The following paragraphs provide for the establishment of close cooperation between the EU Commission and national competition authorities, and that Commission may publish guidelines to assist both the national authorities and undertakings in the sectors concerned.

Articles 207 and 208 introduced broadly applicable definitions ${ }^{82}$, respectively, of «relevant market» and «dominant position», previously provided by the Commission ${ }^{8_{3}}$ and case law of the Court of Justice ${ }^{8_{4}}$, whereas Article 209 (under the heading «Exceptions for the objectives of the CAP and farmers and their associations») represents the «heart» of the legislation, as it outlines a special regime for the agricultural sector, together with Article 2IO, dedicated to «agreements and concerted practices of recognised interbranch organisations».

In particular, Article 209(I), echoing a solution that had been adopted since Regulation (EEC) No. 26/62, establishes the non-applicability of the prohibition under Article IOI(I) TFEU to the agreements, decisions and concerted practices «necessary for the attainment of the objectives set out in Article 39 TFEU». The subjective qualification of the parties who conclude such agreements is irrelevant, so it is not necessary, for the purposes of the derogation, that they all be «agricultural» parties. What is relevant is whether the agreement, decision or concerted practice is essential for attaining the objectives of the CAP; this has been clearly affirmed on more than one occasion in the interpretations of the Court of Justice, which has always judged it necessary to demonstrate the indispensability

${ }^{80}$ Council Regulation (EC) No. II84/200 of 24 July 2006 applying certain rules of competition to the production of, and trade in, agricultural products.

${ }^{81}$ Regulation (EU) No. I379/2013 of the European Parliament and of the Council on the common organisation of the markets in fishery and aquaculture products, amending Council Regulations (EC) No. II84/2006 and (EC) No. I224/2009 and repealing Council Regulation (EC) No. I04/2000, in OJEU L 354/I3.

${ }^{82}$ BlockX and VANDENBerghe, «Rebalancing commercial relations along the food supply chain: the agricultural exemption from EU competition law after Regulation I308/2013», cit., 400; the authors note that the European Parliament had requested that specific definitions of relevant market and dominant position be introduced for the agricultural sector, but the request was eventually rejected.

${ }^{83}$ See, for example, the Commission Notice on the definition of relevant market for the purposes of Community competition law 97/C 372/03, in OJEC C 372 of 9 December 1997.

${ }^{84}$ In this regard see the decisions discussed in POCAR-BARUfFi, Commentario breve ai Trattati dell'Unione europea, II ed., Padova, 20I4, sub Art. IO2 TFEU. 
of the agreement whose admissibility is in question with respect to the pursuit of the objectives set out Article $39 \mathrm{TFEU}^{85}$.

As mentioned above, paragraph I(2) affirms the non-applicability of Article IOI(I) TFEU to agreements, decisions and concerted practices of farmers, farmers' associations, or POs recognised under Article I52, or associations of POs recognised under Article $156^{86}$, which concern the production or sale of agricultural products or the use of joint facilities for the storage, treatment or processing of agricultural products, unless the objectives of Article 39 TFEU are jeopardised. As regards this second specific case, the subjective qualification of the parties to the agreement, decision or concerted practice clearly takes on essential importance; again, the legislative provisions are in line with what has been established by Community law since Regulation (EEC) No. 26/62, with the introduction of an explicit reference to recognised POs and their associations as negotiating entities ${ }^{87}$.

However, the third pre-existing exception related to agreements falling within the framework of a national market organisation was finally formally removed, given that such organisations have no longer existed for some time, having been replaced by the European market organisation.

Once again, it is established (third subparagraph of Article 209(I)) that the whole of paragraph I will not apply to agreements, decisions and practices which entail an obligation to charge identical prices or have the effect of excluding competition: consequently, agreements that lead to such effects are to be considered in any case prohibited ${ }^{88}$.

It is difficult to understand the persistent prohibition (also in the new regulation) concerning prices, which continues to apply both for the agreements and decisions of farmers or farmers associations and the agreements necessary for the attainment of the objectives of the CAP; it is also seemingly not compatible with the power granted to POs in certain sectors to conduct contractual negotiations, which could result in a price being set for subsequent sales transactions.

${ }^{85}$ Cf. Court of Justice, I5 May I975, in case 7I/74, Frubo; Id., I6 December I975, Suiker Unie, in joined cases 40 to 48, 5O, 54 to 56, III, II3 and II4/73; Court of First Instance, I3 December 2006, in joined cases T-2I7 and 245/03, Fédération nationale de la coopération bétail et viande.

${ }^{86}$ The second subparagraph of Art. 209(I) of Regulation No. 1308/2013 expressly clarifies, unlike the previous legislation, that the exemption from the prohibition under Art. IOI TFEU also applies for agreements, decisions and concerted practices of recognised POs or recognised associations of POs. However, even before this explicit wording, there was no doubt that even the previous legislation was applicable to the POs where this point was concerned; the same applies for the agreements, decisions and practices as per Art. 2.I(2) of Regulation II84/2006, though there is no express reference to POs (CANFORA, La disciplina della concorrenza nel diritto comunitario, in CostaTO, Germanò, Rook BASILE, Trattato di dir. agr., vol. 3, Turin, 20II, 209 ff.

${ }^{87} \mathrm{Cf}$. JANNARELLI, «'Agricoltura e concorrenza' o 'concorrenza e agricoltura'?», cit., 25; the author notes that the explicit mention of recognised POs as being among the entities that may conclude agreements and engage in concerted practices is also consistent with the fact that now POs can also have members who are not agricultural producers, provided that they do not control the organisation.

${ }^{88}$ The fact that the prohibition against fixing identical prices is starting to feel the impact of centrifugal forces, amplified by the opening of the market as a result of the new orientations underlying the CAP, clearly emerges with the «endives» issue in France: the Court of Appeal of Paris overturned the decision of the national competition authority, which had imposed penalties on a dozen or so producer associations judged guilty of entering into agreements that were against the law because essentially aimed at fixing minimum selling prices for products; the decision of the Court of Appeal was challenged, so the case is likely to be referred to the Court of Justice for a preliminary ruling: for a discussion on the whole issue and the legal arguments supporting the judgment on appeal, see Del ConT, L'arret de la Cour d'Appel de Paris du 14 mai 2014, «l'affaire endives»: quels enseignements pour l'avenir de la «relation speciale» entre agriculture et concurrence?, in Riv. dir. agr., 20I5, II, 83 ff. 
Moreover, there seems to be no doubt as to the fact that the negotiations conducted by POs can also define the prices of subsequent sales: besides considerations of a systematic and logical character, both recital $139^{89}$ and paragraph 2 (b) of article 149 articles I69 to I7I, in which there is an express reference to a «negotiated price», imply the possibility of setting prices.

In any case, the specific provision, contained expressis verbis in the new regulation, with respect to the setting of prices in the sectors in which POs are authorised to carry out contractual negotiations, necessarily implies a derogation from the general prohibition against charging identical prices which is established by the same regulation ${ }^{90}$. The reason lies also in the principle of speciality, as the special rule is destined to prevail over the general one. This is clarified by Article 206 of the regulation: after establishing the applicability of Article IOI et seq. TFEU, it reaffirms, precisely, the rules laid down by other provisions of the same regulation. However, it would not have been inappropriate to define this derogation with more clarity, especially as the negotiations for the adoption of the new text dragged on for two years, with the involvement of all institutions taking part in ordinary legislative procedures ${ }^{91}$.

It thus appears necessary to coordinate the provisions of Article 209 with those dealing with contractual negotiations conducted by POs, interpreting them to mean that it is prohibited to conclude binding agreements giving rise to an obligation to charge identical prices, with the exception of the specific cases for which the same regulation attributes bargaining powers to the POs (and with the exception of the cases in which the POs - or,

\footnotetext{
${ }^{89}$ Which, on the subject of the bargaining power of POs in the beef and veal and olive oil sectors and for producers of some arable crops, provides that the purpose of such negotiations is to establish, albeit subject to quantitative limits, the terms of (subsequent) delivery contracts, including prices. Recital I28 affirms likewise in regard to the milk and milk products sector, specifying that in order to ensure a fair standard of living for dairy farmers, their bargaining power needs to be strengthened; in order to achieve this objective, POs should be allowed, in accordance with Art. 42 and Art. 43 TFEU, to negotiate the contract terms, including price, for some or all of their members' production, subject to quantitative limits so as to maintain effective competition in the market.
}

$9^{\circ}$ As rightly pointed out by JANNARELLI, in «L'associazionismo dei produttori agricoli ed il tabù dei prezzi agricoli nella disciplina europea della concorrenza», cit., I90, the prohibition against agreements that may oblige members to charge identical prices presupposes that POs only have regulating functions, since direct marketing of the products contributed by members - also envisaged for several production sectors under EU legislation - is incompatible with such a prohibition, whether it takes the form of marketing undertaken by the organisation on behalf of its members, or the organisation itself operates on behalf of its members.

${ }^{91}$ It is worth noting that the agreements arising from the contractual negotiations carried out by POs in the sectors where this is allowed, irrespective of the aspect connected to the fixing of prices, could moreover not benefit from the derogation pursuant to the second subparagraph of Art. 209(I), since such agreements also concern parties other than farmers; thus they should be considered as prohibited, as they do not fall within the scope of the so-called agricultural exception previously provided for under Art. I76 of Regulation (EC) No. I234/07 for products covered by the CMO and now by the second subparagraph of Art. 209(I) of Regulation No. I308/20I3. Nor could the latter be invoked to legitimise agreements concluded as a result of contractual negotiations: in fact, though on the one hand the EU legislator specifies that contractual negotiations carried out by recognised POs in the sectors specified in articles I69, I70 and I7I of Regulation No. I308/20I3 are to be considered instrumental to attaining the objectives of the CAP, as described in Art. 39 TFEU, once the requirements set out therein have been complied with, the same Art. 209 clarifies that the derogation provided for agreements necessary for the attainment of the objectives of the CAP cannot be applied where the agreement, decision or practice implies the obligation of charging identical prices. 
where possible, the $\mathrm{IOs}^{92}$ - directly sell, in their own name and on their own behalf, the products they receive from members $)^{93}$.

The other aspect considered in this paper, namely, the written contract as an instrument for combating the inequalities between agricultural producers and purchasers in terms of information and bargaining power, does not seem to assume relevance for the purpose of applying antitrust legislation. The latter enters into play, for example, in order to prevent horizontal agreements among purchasers, as well as in the above-described cases regarding agreements among agricultural producers or supply chain agreements; to prevent abuses of dominant position, where the potential exists; and to control concentrations between undertakings that intend to expand their size and thereby gain undue strength in the market. The inequality of bargaining power and the possible abuses by the party with greater power (whenever - as in the majority of cases - the latter does not have a dominant position in the market) are not generally taken into consideration by European competition law ${ }^{94}$.

As we have seen, the protection of the weak contracting party against possible abusive behaviours of the counterparty is substantially left up to the Member States, given that, at least as regards business-to-business relations, EU law only ventured a first timid approach with Regulation (EU) No. 26I/I2 in relation to formal written contracts with first purchasers of milk and milk products, later extending that solution to all sectors of the CMO with Article 168 of regulation (EU) No. 1308/2013 $3^{95}$.

Lacking any direct intervention on the part of $\mathrm{EU}$ law, this aspect is thus substantially left up the Member States, some of which, as we saw previously, have taken initiatives in this regard, exploiting the possibility of being able to address abusive conduct through regulatory provisions, even where the individual or entity that engages in such behaviour does not hold a dominant position. A prime example in this respect is the legislation, present in some Member States, which is designed to repress abuse of

${ }^{92}$ Art. 210 addresses the agreements and concerted practices of recognised IOs.

${ }^{93}$ In this regard, see recital I3I, according to which POs and their associations can play useful roles in concentrating supply, improving marketing and adjusting production to demand, optimising production costs and stabilising producer prices.

${ }^{94}$ It is a well-established opinion that the aspects related to contracts concluded between parties with unequal bargaining power are not normally relevant for EU antitrust law, which rather focuses on situations of so-called buyer power: the latter is considered to exist if and to what extent a market is so concentrated «that a particular buyer has not only power over a particular supplier but over suppliers in general» (as stated in par. 73 of the Report on competition law enforcement and market monitoring activities by European competition authorities in the food sector, issued by the ECN - European Competition Network, May 20I2; on this point see also the Commission working document Competition in the food supply chain, accompanying the Communication A better functioning food supply chain in Europe, in http://ec.europa.eu/economy_finance/publicatyions/publicationi6o65_en.pdf, as well as, among others, Chauve, Parera, Renckens, Agriculture, Food and Competition law: moving the borders, cit., 306, in which the authors distinguish between situations in which there is an unequal bargaining power between the parties to a contract and those concerning cases of buyer power, since only the latter constitute, as a rule, cases that are relevant for competition law, where «buyer power normally concerns situations in which the power of a buyer can affect the whole market» (pág. 3II).

${ }^{95}$ In reality, some provisions, despite being fragmentary and inadequate, can be used in an attempt to combat the phenomenon; for example, those concerning late payments in commercial transactions and those aimed at protecting not only consumers, but competitors as well, against deceptive and comparative advertising. 
economic dependence ${ }^{96}$. Recital (9) of Regulation (EC) No. $\mathrm{I} / 2003^{97}$ is very clear on this point, as it states explicitly that «this Regulation ... does not preclude Member States from implementing on their territory national legislation, which protects other legitimate interests provided that such legislation is compatible with general principles and other provisions of Community law»; by way of example, the recital mentions legislation that «prohibits or imposes sanctions on acts of unfair trading practice, be they unilateral or contractual ... irrespective of the actual or presumed effects of such acts on competition on the market. This is particularly the case of legislation which prohibits undertakings from imposing on their trading partners, obtaining or attempting to obtain from them terms and conditions that are unjustified, disproportionate or without consideration $»^{98}$.

However, as pointed out by the Commission itself, though on the one hand the rules established by a number of Member States in this regard highlight how widespread the problem is, not being confined within one or more Member States, but rather common to all undertakings operating throughout EU territory, on the other hand they lack uniformity $^{99}$ - nor could it be otherwise, in the absence of any harmonising legislation both as far as the identification of abusive conducts is concerned and with respect to penalties. It would thus certainly not be inappropriate to address the issue within the framework of EU law, also because, as pointed out previously, the present situation implies a patchwork of national provisions which inevitably affect transnational contractual relations as well, not to mention the proper functioning of the internal market ${ }^{100}$.

With specific reference to the agri-food sector, a few reservations, however, should be expressed in respect of the affirmation made by antitrust law specialists that unfair or abusive practices regarding individual contractual relations and resulting from the inequality between the parties in terms of bargaining power are irrelevant for the purposes of competition legislation. That is because such cases, notwithstanding the presence of

${ }^{96}$ For an examination of national legislation on this point, see International Competition Network, Special Program for Kyoto Annual Conference, Report on Abuse of Superior Bargaining Position, http://www.internationalcompetitionnetwork.org/uploads/library/doc386.pdf.

97 Council Regulation (EC) No. I/2003 of I6 December 2002, in OJEC L I del 4.I.2003, on the implementation of the rules on competition laid down in Articles 8I and 82 of the Treaty.

$9^{8}$ The Report on competition law enforcement and market monitoring activities by European competition authorities in the food sector, cit., highlights that «national rules may have a different perspective» from EU competition law (note 65).

${ }^{99}$ Cf. Libro verde sulle pratiche commerciali sleali nella catena di fornitura alimentare e non alimentare tra imprese in Europa, cit.; see also HeNNING-BodEWIG (ed.), International Handbook on Unfair Competition, Munchen, 20I3; HELLWEGE, «It is necessary to strictly distinguish two forms of fairness control!», in Journal of European Consumer and Market Law, 4/20I5, I29 ff..

${ }^{100}$ On this subject, see GonZÀLEZ VAQUÉ, «Unfair Practices in the Food Supply Chain», in EFFL, 5/20I4, 293 ff. Hilty,Henning-Bodewig, Podszun, Comments of the Max Planck Institute for Intellectual Property and Competition Law, Munich of 29 Aprile 2013 on the Green Paper of the European Commission on Unfair Trading Practices in the Business-to-Business Food and Non-Food Supply Chain in Europe, available at the website http://www.ip.mpg.de/fileadmin/templates/pdf/MPI_Stellungnahme_Gruenbuch_B2B_20I3-04-30_oI.pdf, believe that the concerns raised by the Commission in Green Paper of the European Commission on Unfair Trading Practices in the Business-to-Business Food and Non-Food Supply Chain, cit. in relation to the implications of distinct national legislation on transnational trade, are to be considered excessive. In this regard, it should be noted that Art. 86 of the Proposal for a Regulation of the European Parliament and of the Council on a Common European Sales Law of II.IO.20II, COM (20II) 635 envisages the possibility of considering the terms of contracts between traders to be unfair; the proposal does not seem likely to be approved, however, as the Juncker Commission recently declared that it wanted to withdraw it and intends to submit new proposals on the subject of ecommerce and the supply of digital content (on this point see SchulzE, «The New Shape of European Contract Law», in Journal of European Consumer and Market Law, 4/2015, I40. 
aspects that are pathological in some respects, allegedly do not affect the structure of the market as a whole, being limited to the single contractual relationship concerned, which involves parties - businesses in this case - having different bargaining power.

Yet in the case of relations in the agricultural and food supply chain, the existence of a marked difference in bargaining power cannot be considered an isolated phenomenon, limited to a number of specific contractual relations or characterising only a few specific businesses. On the contrary, the situation in question has relevance at a system level, as it concerns a whole set of contracts between sellers, on the one hand, and purchasers, on the other. Therefore, although from a theoretical perspective the distinction between aspects tied to unequal bargaining power and buyer power ${ }^{101}$ is clear and precise, if we examine the contractual relations among businesses operating in the agricultural and food products supply chain as a whole, we can easily understand that the distinction becomes fuzzy, to the point of disappearing, since the undisputed greater bargaining power of purchasers in general implies - if and to the extent that it enables abusive or unfair practices - a serious risk of undermining the proper functioning not only of individual contractual relationships, but of the entire market. Unexpected and/or retroactive modifications of contract terms and conditions, abrupt withdrawals devoid of any real justification and penalising price policies not only impose a severe burden on a business that falls victim to them, but, if they occur on a large scale, they can induce sellers to make fewer investments in the absence of adequate certainty about the profit they can expect. This means less product innovation and less choice for consumers; furthermore, it has been clearly shown that although the greater bargaining power of distribution or processing companies means lower prices for suppliers, it does not always imply that the benefits obtained by the stronger contracting party will trickle down to consumers.

Therefore, although it is undoubtedly correct to say that the agricultural market cannot be considered devoid of rules when it comes to the protection of competition, and that oversight is required to ensure the proper application both of antitrust law in general and the exceptions provided for the agricultural sector, it is likewise indisputable that the attention of the Commission, and particularly of Directorate-General for Competition, cannot not focus only on the anti-competitive implications of the activity of organisations of agricultural producers or interbranch organisations, or on the contractual negotiations conducted by POs, where - with many ambiguities and uncertainties - the EU legislator has established numerous requirements and conditions that must be met in order for such negotiations to be considered legitimate. The Commission should rather start asking itself whether the aspects concerning bargaining power in the agricultural and food products sector, given their systemic nature, might not actually have a relevant bearing on the concerns tied to buyer power, one of the central aspects of EU competition law ${ }^{\text {102 }}$.

\footnotetext{
${ }^{\text {ror }}$ What is more, the existence of situations that may be associated with buyer power is not always in contrast with antitrust rules, particularly when such situations imply benefits for consumers: Cf. the Commission working document Competition in the food supply chain, cit.

${ }^{\text {Ioz }}$ Chauve, Parera, Renckens, Agriculture, food and Competition law: moving the borders, cit., 3I2; the authors note that, following reports received from the parties concerned and some national competition authorities, in which it was deduced that the «network of bargaining power practices (of operators which do not individually have buyer power and are not linked) would ultimately have the same detrimental effect as buyer power», the Commission commissioned a study to assess such possible effects.
} 